\title{
Space Architecture for MoonVillage
}

\author{
Brent Sherwood* \\ Jet Propulsion Laboratory, California Institute of Technology, Pasadena, CA, 91109
}

\begin{abstract}
The concept of a multinational MoonVillage, as proposed by Jan Wörner of ESA, is analyzed with respect to diverse factors affecting its implementation feasibility: potential activities and scale as a function of location, technology, and purpose; potential participants and their roles; business models for growth and sustainability as compared to the ISS; and implications for the field of space architecture. Environmental and operations constraints that govern all types of MoonVillage are detailed. Findings include: 1) while technically feasible, a MoonVillage would be more distributed and complex a project than the ISS; 2) significant and distinctive opportunities exist for willing participants, at all evolutionary scales and degrees of commercialization; 3) the mixed-use space business park model is essential for growth and permanence; 4) growth depends on exporting lunar material products, and the rate and extent of growth depends on export customers including terrestrial industries; 5) industrial-scale operations are a precondition for lunar urbanism, which goal in turn dramatically drives technology requirements; but 6) industrial viability cannot be discerned until significant in situ operations occur; and therefore 7) government investment in lunar surface operations is a strictly enabling step. Because of the resources it could apply, the U.S. government holds the greatest leverage on growth, no matter who founds a MoonVillage. The interplanetary business to be built may be cause for engagement.
\end{abstract}

$\begin{array}{ll} & \\ \text { CHNPS } & =\text { Carbon, Hydrogen, Nitrogen, Phosphorus, Sulfur } \\ \text { CNSA } & =\text { Chinese National Space Agency } \\ \text { EM-L1 } & =\text { Earth-Moon Lagrange Point } 1 \\ \text { ESA } & =\text { European Space Agency } \\ \text { GDP } & =\text { Gross domestic product } \\ I S S & =\text { International Space Station } \\ \text { KREEP } & =\text { Potassium, Thorium, Rare Earth Elements, and Phosphorus } \\ \text { LED } & =\text { Light emitting diodes } \\ \text { LEO } & =\text { Low Earth orbit } \\ \text { NRC } & =\text { National Research Council } \\ R S A & =\text { Roskosmos } \\ S S P & =\text { Space solar power }\end{array}$

\section{Introduction}

$\mathrm{I}_{\mathrm{c}}^{\mathrm{n}}$ 2015 Jan Wörner, Director General of ESA, introduced an idea called "MoonVillage" into the international conversation about destinations and purposes for human space flight. ${ }^{1}$ Simply put, multiple nations and companies would bring systems and perform self-determined operations at a common location on the Moon, so that they all could benefit from the synergy of collocation, shared services, and economies of scale.

Wörner is quick to note that this is one suggestion for how to move humanity forward in lunar activities; that its primary purpose as a meme is to be a conceptual catalyst for conversation, concept formulation, and strategy making; and that a measure of progress would be supplanting the meme with a "better" one. Indeed, no single lunar location could enable all potential uses and users, so a singular MoonVillage cannot be universal. However, the idea has generated some traction as originally proffered. ${ }^{2,3,4}$

\footnotetext{
*Jet Propulsion Laboratory, California Institute of Technology. Space Architect; Program Manager, Solar System
} Mission Formulation. 4800 Oak Grove Drive, M/S 321-625, Pasadena, CA 91109. 
What are the implications for space architecture of such a mixed-use, multi-player concept as MoonVillage - for site planning, systems, operations, outfitting, technical support, and the other manifold considerations of space architecture?

This paper explores how implementation and growth of MoonVillage space architecture might fit into the known framework of lunar surface conditions, the evolving framework of national and commercial interests for lunar activities, emergent knowledge about lunar science and resources, and the literature about mixed-use space infrastructure. Issues of scale and technology type as a function of population size, activities, and location on the lunar surface reveal principles for how a MoonVillage could work and be built, and the enabling capabilities for this to happen.

\section{MoonVillage as a Mixed-Use Space Business Park}

Concepts for lunar colonies over the first half-century of space flight have tended toward one of three general types: scientific base; mining settlement; lunar city.,

While useful as archetypes, single-purpose concepts are an impractical model for large-scale development of lunar activities. The most apt evidence for this conclusion is the historical contrast between vision and reality for Earth-orbiting space stations. Both Mir and Space Station Freedom were conceived as microgravity research laboratories whose development and utilization was to be funded by single governments. Because of Freedom's ambition (and hence, expense), it saw fruition as the International Space Station only once broadened into a multinational project, albeit still with an almost singular research purpose. ${ }^{7}$ And today, just five years after assembly-complete, its continued existence beyond 2024 appears to hinge on viable planning for a transition to commercial ownership and operation as its patron governments shift their investments outward, beyond Earth orbit. ${ }^{8}$ Options are under discussion now.

However, the end of Mir provides a sobering precedent: commercial viability of an aging, habitable, singlepurpose orbital asset, transitioned to applications other than fundamental research, is not assured. ${ }^{9}$ Obstacles for a successful transition from government-funded, fundamental-research laboratory to commercially-viable operations facility include: high capital costs for extending life as the asset ages, exacerbated due to the expertise oligopoly held by the asset's industrial developers; "overkill" requirements compared to the needs of diverse non-research users, which inflates sustainment costs; "closed" architecture resulting from cost-based compromises during development, that limit retrofit flexibility needed for the transition.

An alternative model was proposed in the literature in the early 1990s, even before Zvezda, the first ISS module, was launched and while Mir was still in its operational heyday: the mixed-use business park. ${ }^{10,11,12} \mathrm{~A}$ mixed-use space business park would adapt well-understood terrestrial business real estate practices, facilitating from the start the economically viable establishment and growth of diverse spacefaring enterprises. Individual enterprises invest only in the unique capabilities, equipment, and materiel they need respectively; each pays fees for transportation and facility services, thereby buying the opportunity and freedom to innovate. The business park itself develops, owns, and operates the common facility (just as transportation providers own and operate their vehicles), taking on the financial risk of securing and sustaining user tenants. Individual tenants' business cases can close because they are spared the otherwise insurmountable infrastructure costs (a traditional role of government investment in opening new market areas). In turn, the facility's business case can close by avoiding the need to be engaged, expert, or successful in highly specialized space-utilization enterprises.

No single enterprise bears the full burden of driving all facility requirements; thus no single use type (e.g., fundamental research) dominates the architecture, capabilities, capacity, or operating costs (this is where the business park model differs from the model of adapting a laboratory like ISS). Standard, common-denominator services provide tenants a predictable operating environment, e.g., for security, utilities, and leases, all of which are essential for them to obtain their own financing. While reconciling the requirements of diverse activity types is not easy, tenant diversity provides a robust business base for the business park. Individual tenants' businesses may grow or fail, but the facility's own business case, based on a portfolio of tenants, goes on.

The published concept of an Earth-orbiting, mixed-use space business park can be adapted to the Moon, and thus be relevant to MoonVillage. At first, this might appear self-evident - were the model to be applicable independent of location. But it is not. Specifically, asteroids are untenable locations for this model because each is an astrodynamically singular site, and the only potential commercial business is mining. Mining colonies perhaps, but business parks, not foreseeably. And Mars is an untenable near-term location for the model because the economics of high-capacity interplanetary transportation favor the Moon, essentially forever. 
To a lesser degree than LEO, but more than these other deep-space destinations, the Moon proffers multiple opportunities of potential interest to diverse pioneers: scientific, governmental, and commercial. Only "three days away," the Moon is in fact the next destination aspiration for many of the spacefaring organizations discussed next.

\section{MoonVillage Players}

Deep into humanity's second half-century of space flight, many capable "players" have set their sights on the Moon in a contemporary redux of what motivated the first "space race": the Moon is a routinely visible, tangibly close, but technologically challenging destination. Reaching it demonstrates space flight prowess; and operating there routinely could open opportunities. Loosely grouped, there are three types of players capable of bringing resources to bear, who are interested in lunar activities today:

Group I - the "big four" government spacefarers. Three government programs - based in Russia, the USA, and China - have operated on the Moon already, and ESA probably could if it chose to. Each major government player is subject to unique pragmatic constraints. Only the USA has ever achieved human lunar surface missions; but presently it cannot and does not plan to. Both Russia and China have operated roving robots on the lunar surface. Russia is perennially constrained financially, and has recently converted its space agency into a state corporation and announced a 30\% reduction in decadal funding. ${ }^{13,14}$ China presented its human lunar strategy in $2015 .{ }^{15}$ All four powers have large-scale space flight enterprises capable of building, launching, and operating habitable lunar spaceflight systems. This means that if motivated, any of these four could competitively or collaboratively match projects undertaken by the others; or overtake activities pioneered by players in the other groups.

Group II - emergent and supporting government spacefarers. Many other government space flight programs - including those of Japan, Canada, India, Korea, Brazil, and the United Arab Emirates - demonstrate some combination of interplanetary or lunar orbital mission experience, partnership experience on the ISS, launch experience, lunar mission ambitions and projects, and related interplanetary mission capabilities. None has the capacity individually to motivate or establish a MoonVillage. But because they all use space flight as a catalyst for technological innovation, public inspiration, and demonstration of prowess, they would tend to actively seek niche involvement in multinational lunar activities opened by or led by others, each according to their unique expertise (e.g., Canadian robotic manipulators) or strategic goals (e.g., Japanese autonomous landing). Niche roles would exist for scientific-instrument expertise historically funded by national governments in Europe and Russia.

Group III - industrial spacefarers. Various public and private space companies have an expressed or latent interest in lunar activities. The diacritical subgroups are "oldspace" and "newspace."

Oldspace companies tend to have established relationships with traditional government customers, and established supply-chain networks. Responsibility to shareholders and business inertia constrain them to follow their customers' money and interests, including lunar activities that may be pursued by Groups I or II.

Newspace companies tend to be motivated by a combination of charismatic vision, commitment to disruptive principles, and the potential for breakthrough profits from new customers and new ("blue ocean") markets. Three lunar-relevant sub-groups comprise companies pursuing the Google Lunar X-Prize for landing and operating on the surface (e.g., SpaceIL, Moon Express, Astrobotic); companies pioneering launch reusability and cost-reduction (i.e., Space X); and companies set on mining space resources (e.g., Shackleton Energy Company, Space Resources Inc., and Planetary Resources).

The Boeing Company exemplifies an interesting crossover between oldspace and newspace: traditional government prime contractor and co-owner of United Launch Alliance, yet primarily self-funding development of its CST-100 Starliner commercial crew spacecraft.

For a MoonVillage, the key attribute of industrial spacefarers is that increasingly, they will be able to reach the Moon on their own, outside the framework of government projects. To appreciate the significance of this state change, consider the industrialization of the geostationary orbit for telecommunications: demonstration of core capabilities by governments opened a new market, whose privately funded exploitation has now changed our world.

All three groups of players are highly likely to participate in a MoonVillage, and the multi-player precedent of terrestrial mixed-use business parks implies that all three would likely be essential. Group I could undertake primary investment to retire major technical risks, emplace common infrastructure, and anchor services markets; Group II could provide technical specialties and functional redundancies, and promote multinational collaboration and standards of conduct; and Group III could provide services, an early profit mindset, and disruptive innovation. However, to enable long-term growth of a MoonVillage, only Group III could attract or use private capital in excess of government-sponsor budgets. 
If all three player groups are indeed essential for sustainable growth of a MoonVillage, then their respective requirements and expectations are essential also: concepts, plans, operating environments, and standards must accommodate this diversity for a viable, sustainable MoonVillage.

\section{MoonVillage Activities}

MoonVillage "citizens" may have quite divergent interests; an organizing framework can put them in context (Tables 1-4). These tables reveal the breadth and diversity of potential activities that could be undertaken. Some important patterns emerge:

- Lunar science is fundamental. Learning about lunar conditions and how they change, and about lunar materials and the states they may be found in, underpin all types of activities beyond short expeditions.

- We know essentially nothing about $\mathbf{1 / 6}$ g. Gravity pervades all matter and shapes the physics of all materials, physical systems, and biological systems. As activities increase in complexity, scale, and duration, the more important partial-gravity science becomes.

- Practical knowledge is pivotal. An enormous body of pragmatic learning is essential, yet so far is almost vacant. Because this knowledge is both precursory and empirical, we cannot effectively design systems to support routine operations until we are already operating in the lunar environment. This in turn means that a key MoonVillage activity would be continuous experimentation, and the resulting expertise could be highly marketable to subsequent players.

- Many activities can be sold as services. This is good news for a healthy MoonVillage, as it allows almost instantly a barter economy and opportunities for profit-making. Possible allocations between government and commercial responsibility, and crossover criteria, are treated below.

- A settlement orientation changes everything. By complexity and cost, most of the activities listed are driven directly and solely by a requirement for indefinite occupancy, and a related requirement to support a growing population. Sociological issues arise for groups larger than a single mission crew; genuine urban issues arise as specialization increases (certainly by the scale of $10^{2}$ residents). Both sets of issues take human space flight into new territory, requiring new technologies, designs, equipment, and accommodation solutions far beyond what has been demonstrated. A pivotal takeaway is the inverse of this finding: ignoring a settlement orientation would, even if inefficient in the long run, minimize barriers-to-entry for initial creation of a MoonVillage, by sidestepping a vast array of technical challenges and joint decisions. The strong economic disincentive to invest more than tactically necessary almost guarantees MoonVillage growth to be inefficient, somewhat haphazard, and subject to continual outgrowth and retrofitting. For terrestrial urban planners this is a familiar and lamentable, even if unavoidable, pattern.

Table 1. Science investigation activities for a MoonVillage.

\begin{tabular}{|c|c|c|}
\hline \begin{tabular}{|c|}
$\begin{array}{c}\text { Activity, Purpose, } \\
\text { Product }\end{array}$ \\
\end{tabular} & Explanation \& Examples & Significance \\
\hline $\begin{array}{c}\text { Scientific } \\
\text { investigation }\end{array}$ & $\begin{array}{l}\text { Understanding natural processes that constrain what the } \\
\text { Moon offers and allows us to do }\end{array}$ & Governs all other activities \\
\hline $\begin{array}{l}\text { Environmental } \\
\text { context of the } \\
\text { Moon }\end{array}$ & $\begin{array}{l}\text { Space environment surrounding the Moon. } \\
\text { Moon's dynamic exosphere. }\end{array}$ & $\begin{array}{l}\text { Defines fundamental engineering parameters: } \\
\text { temperature, radiation, insolation, tribology... } \\
\text { Constrains volatiles: sources, distribution, state, } \\
\text { mobility. }\end{array}$ \\
\hline \multirow{3}{*}{ Lunar geology } & $\begin{array}{l}\text { Geophysics of the Moon as a telluric planetary body (formation, } \\
\text { differentiation, volcanism, tectonism, and exogenic modification) }\end{array}$ & Constrains solid materials (abundance, form) \\
\hline & $\begin{array}{l}\text { Geochemistry of areas of interest (elemental composition, } \\
\text { mineralogy, weathering) }\end{array}$ & $\begin{array}{l}\text { Constrains accessible solid and volatile materials } \\
\text { including all "ores" (states, form, mixtures) }\end{array}$ \\
\hline & $\begin{array}{l}\text { Surface modification processes (seismic activity, thermal cycling, } \\
\text { meteorite gardening, space weathering) }\end{array}$ & $\begin{array}{l}\text { Surface states, mechanical properties, chemical } \\
\text { and physical durability }\end{array}$ \\
\hline \begin{tabular}{|l|} 
Lunar-based \\
science operations
\end{tabular} & $\begin{array}{l}\text { Use of radio-quiet Farside to emplace, maintain, and permanently } \\
\text { operate large radio astronomy antenna arrays }\end{array}$ & $\begin{array}{l}\text { Unique solar system location enables a new } \\
\text { window into the universe }\end{array}$ \\
\hline 1/6-g physics & $\begin{array}{l}\text { Behavior of granular materials, fluids, and plasmas (including } \\
\text { flame) on the Moon }\end{array}$ & $\begin{array}{l}\text { Unprecedented gravity regime reshapes all } \\
\text { familiar natural physical behaviors }\end{array}$ \\
\hline $\begin{array}{l}\text { 1/6-g and hermetic } \\
\text { biology }\end{array}$ & $\begin{array}{l}\text { Short-term and long-term adaptation of macromolecules, } \\
\text { organisms from all kingdoms of Earth life including humans and } \\
\text { human microbiota, and ecologies. } \\
\text { Psychology and sociology. }\end{array}$ & $\begin{array}{l}\text { Required for operationally useful human residence } \\
\text { time and... } \\
\text { Establishment, operation, and perpetuation of a } \\
\text { closed ecology that sustains humans. }\end{array}$ \\
\hline
\end{tabular}


Table 2. Practicum activities for a MoonVillage.

\begin{tabular}{|c|c|c|}
\hline $\begin{array}{l}\text { Activity, Purpose, } \\
\text { Product }\end{array}$ & Explanation \& Examples & Significance \\
\hline Practicum & $\begin{array}{l}\text { Learning the basics about how human systems can function } \\
\text { in the lunar environment }\end{array}$ & $\begin{array}{c}\text { Essential, marketable pragmatic experience in } \\
\text { making things work, including keeping systems } \\
\text { running and people healthy and positive in this } \\
\text { unprecedented place }\end{array}$ \\
\hline $\begin{array}{l}\text { Environmental } \\
\text { management }\end{array}$ & $\begin{array}{l}\text { Dust control and tribological management. Radiation shielding. } \\
\text { Impact shielding. Thermal regulation. Power management. } \\
\text { Safety. }\end{array}$ & $\begin{array}{l}\text { Learning to operate within or despite native } \\
\text { conditions, and how to use them to inspire and } \\
\text { enable elegant designs and operations. }\end{array}$ \\
\hline $\begin{array}{l}\text { Industrial } \\
\text { operations }\end{array}$ & $\begin{array}{l}\text { Adaptation, practice, refinement, scaleup, and management of } \\
\text { safe and predictable operations to produce and manage power, } \\
\text { control environmental conditions, and make engineering materials }\end{array}$ & $\begin{array}{l}\text { Required for permanence and growth of large- } \\
\text { scale operations }\end{array}$ \\
\hline Kitchen science & $\begin{array}{l}\text { "How to cook an omelette and mix a martini." } \\
\text { Hygiene and grooming. } \\
\text { Safety. Cleaning. Repairing. } \\
\text { Art. }\end{array}$ & $\begin{array}{l}\text { Enables development of quotidian activities } \\
\text { (substance behaviors, processes, movement, } \\
\text { technique, design and use of specialized tools and } \\
\text { equipment, safety). } \\
\text { Stimulates creative innovation and art. } \\
\end{array}$ \\
\hline $\begin{array}{l}\text { Habitation } \\
\text { operations }\end{array}$ & $\begin{array}{l}\text { Life support and environmental control. } \\
\text { Safety. Maintenance. } \\
\text { Architecture. Private and Public accommodation. Sports and } \\
\text { recreation. } \\
\end{array}$ & $\begin{array}{l}\text { Required to assure lifesafety and routine operations } \\
\text { at all habitation scales. } \\
\text { Required for scaling up from single-ship crews } \\
\text { toward settlement populations }(\sim 100-1000) \text {. } \\
\end{array}$ \\
\hline Urban operations & $\begin{array}{l}\text { Utilities: air, water, power, network, temperature, sewer, } \\
\text { recycling. } \\
\text { Safety of construction and operations. Zoning. } \\
\text { Transportation of goods and people. Supply chain. } \\
\text { Human assembly. Sports and recreation. } \\
\text { Security. }\end{array}$ & $\begin{array}{l}\text { Required to enable social living in an intrinsically } \\
\text { lethal place. }\end{array}$ \\
\hline $\begin{array}{l}\text { Exploration } \\
\text { preparation }\end{array}$ & $\begin{array}{l}\text { Researching, developing, testing, and rehearsing systems, } \\
\text { operations, and crews for deep-space exploration. }\end{array}$ & $\begin{array}{l}\text { Useful as an intermediate, confidence-building step } \\
\text { for humans to Mars or other places more than a } \\
\text { few days away from Earth. }\end{array}$ \\
\hline
\end{tabular}

Table 3. Resource utilization activities for a MoonVillage.

\begin{tabular}{|c|c|c|}
\hline $\begin{array}{l}\text { Activity, Purpose, } \\
\text { Product }\end{array}$ & Explanation \& Examples & Significance \\
\hline $\begin{array}{l}\text { Resource } \\
\text { utilization }\end{array}$ & $\begin{array}{c}\text { Use of native material to obtain basic resources and produce } \\
\text { engineering materials at all scales }\end{array}$ & $\begin{array}{l}\text { Essential, marketable activities for human and } \\
\text { machine activity to grow beyond exploration- } \\
\text { scale }\end{array}$ \\
\hline \multirow{4}{*}{ Mining } & $\begin{array}{l}\text { Volatiles from heated regolith: water, oxygen, hydrogen, carbon, } \\
\text { nitrogen, phosphorus, and sulfur (adsorbed from solar wind and } \\
\text { deposited by impactors) }\end{array}$ & $\begin{array}{l}\text { Breathing air and drinking water. Biomass. } \\
\text { Propellant. } \\
\text { Radiation shielding. } \\
\text { Industrial processes. }\end{array}$ \\
\hline & $\begin{array}{l}\text { Iron from magnetic beneficiation of regolith: native iron grains in } \\
\text { regolith (reduced by solar-wind hydrogen) }\end{array}$ & $\begin{array}{l}\text { Widely useful metal from a unique resource on the } \\
\text { airless Moon. }\end{array}$ \\
\hline & Regolith & $\begin{array}{l}\text { Beneficiation yields raw material for dust control and } \\
\text { siteworks: berms, paving gravel, compacted } \\
\text { regolith, radiation shielding, and feedstock for } \\
\text { sintered and cast-glass products. }\end{array}$ \\
\hline & Minerals: from crystals and chemical complexes comprising rock & $\begin{array}{l}\text { Construction materials. } \\
\text { Metals, semiconductors, trace elements. }\end{array}$ \\
\hline Processing & $\begin{array}{l}\text { Safe physical, thermal and chemical beneficiation and } \\
\text { conversion, to produce industrial feedstock }\end{array}$ & $\begin{array}{l}\text { Required for design and operation of in situ } \\
\text { manufacturing equipment and processes. }\end{array}$ \\
\hline $\begin{array}{l}\text { Manufacture of } \\
\text { substances }\end{array}$ & $\begin{array}{l}\text { Safe production, handling, storage, and transportation (gases, } \\
\text { plasmas, liquids, solids). }\end{array}$ & Basis of any products made in situ. \\
\hline $\begin{array}{l}\text { Manufacture of } \\
\text { structure elements }\end{array}$ & $\begin{array}{l}\text { Structural sections, concrete. } \\
\text { Tanks, piping. } \\
\text { Pressure-vessel components and systems. } \\
\text { Safety. }\end{array}$ & $\begin{array}{l}\text { Required to build Class } 3 \text { structures, which are in } \\
\text { turn required for cost-efficient growth. }\end{array}$ \\
\hline
\end{tabular}


Table 4. Urban development activities for a MoonVillage.

\begin{tabular}{|c|c|c|c|}
\hline \multicolumn{2}{|c|}{$\begin{array}{l}\text { Activity, Purpose, } \\
\text { Product }\end{array}$} & Explanation \& Examples & Significance \\
\hline \multicolumn{2}{|c|}{ Urban development } & $\begin{array}{l}\text { Applying the practicum, to scale up the use of local resources, to } \\
\text { support diversifying activities by a growing human population. }\end{array}$ & $\begin{array}{l}\text { Marketable activities required to } \\
\text { plan, build, and operate human } \\
\text { settlements at scales from camp } \\
\text { to city. }\end{array}$ \\
\hline \multirow{10}{*}{ Internal } & Site & $\begin{array}{l}\text { Surveying, site planning. } \\
\text { Site construction (grading, excavation, deposition, paving, foundations, } \\
\text { stabilization, sealing) } \\
\text { Infrastructure emplacement, recycling }\end{array}$ & $\begin{array}{l}\text { Foundation for all sessile } \\
\text { architecture and traffic. }\end{array}$ \\
\hline & Building & $\begin{array}{l}\text { Methods for design, fabrication, assembly, construction, expansion, test, } \\
\text { verification, deconstruction. }\end{array}$ & $\begin{array}{l}\text { Required to build and certify Class } 2 \\
\text { and } 3 \text { structures (including habitats). }\end{array}$ \\
\hline & Habitation & $\begin{array}{l}\text { Apartments, offices, assembly and recreation spaces, laboratories and } \\
\text { industrial plants, farms and gardens, maintenance spaces, } \\
\text { transportation systems. }\end{array}$ & $\begin{array}{l}\text { Essential building units of all } \\
\text { occupied volumes for diverse } \\
\text { purposes. }\end{array}$ \\
\hline & Life support & $\begin{array}{l}\text { Biological conditioning of air and water. } \\
\text { Operational buffers. } \\
\text { Physicochemical emergency backup systems. }\end{array}$ & \multirow{7}{*}{$\begin{array}{l}\text { Required to sustain people } \\
\text { indefinitely. }\end{array}$} \\
\hline & Food sourcing & Production, processing, packaging, distribution, and composting of food. & \\
\hline & Waste processing & $\begin{array}{l}\text { Collection, stabilization, packaging, transportation, recycling, } \\
\text { repurposing, decomposition (gray water, sewage, biohazards, refuse, } \\
\text { food byproducts, industrial byproducts, manufactured products) }\end{array}$ & \\
\hline & Maintenance & $\begin{array}{l}\text { Routine access, inspection, cleaning, troubleshooting, disassembly, } \\
\text { repair, upgrade, reassembly, test, verification. }\end{array}$ & \\
\hline & Support services & $\begin{array}{l}\text { Retail (shopping, grooming, laundry, tailoring, domestic design). } \\
\text { Health care, funeral. }\end{array}$ & \\
\hline & Social services & $\begin{array}{l}\text { Security, safety. } \\
\text { Education, training. } \\
\text { Governance. }\end{array}$ & \\
\hline & Recreation & $\begin{array}{l}\text { Open spaces, parks, assembly halls, arenas, theaters, sport courts, } \\
\text { pools, restaurants, bars, clubs. }\end{array}$ & \\
\hline \multirow{9}{*}{ Export } & \multirow{3}{*}{ Information } & Knowledge about the Moon. & \multirow{2}{*}{ Science sponsors. } \\
\hline & & Science data generated on the Moon. & \\
\hline & & Lessons learned about operating on the Moon. & \multirow{3}{*}{$\begin{array}{l}\text { Potentially, spacefaring customers } \\
\text { (space transportation, human } \\
\text { mission, and space industries). }\end{array}$} \\
\hline & Oxygen, hydrogen & Propellant. & \\
\hline & $\begin{array}{l}\text { Volatiles, metals, } \\
\text { raw materials }\end{array}$ & $\begin{array}{l}\text { Water, breathing air, biomass. } \\
\text { Shielding, reaction mass. } \\
\text { Industrial products. }\end{array}$ & \\
\hline & \multirow{2}{*}{ Minerals } & Rare Earth Elements & Terrestrial manufacturing industries \\
\hline & & $3 \mathrm{He}$ & Potentially, terrestrial energy industry \\
\hline & Entertainment & Novel sports and art & Terrestrial media markets \\
\hline & Experience & Hosting non-specialist guests & Tourism \\
\hline
\end{tabular}

- Exports enable growth. While not self-evident from the tables, consideration of export activities allows cataloguing the types of product that external players might be interested to buy. Some are contingent (e.g., the undeveloped terrestrial market for ${ }^{3} \mathrm{He}$ requires significant technical breakthroughs before it could become real); and some interest only spacefaring customers (a limited financial pool). The known costs of developing and operating complex, and especially human-rated, space systems preclude growth to settlement scale unless extragovernmental resources are tapped, which in turn strictly requires profit-making exports to Earth.

\section{Moon Village Environment}

Any type and all stages of a MoonVillage can only exist within the physical and operating environment the lunar surface provides and allows. Chapter 14 in Out of This World: the New Field of Space Architecture describes these constraints, summarized in Tables 5 and 6 :

"A first-generation lunar outpost is a major space project likely to require sponsorship by one or more governments. Such an outpost differs in two basic ways from large terrestrial construction endeavors. First, there is no large, preexisting experience base of directly relevant, successful design solutions. Second, despite that lack of knowledge an early base 
can only embody a very few approaches. Vast monetary resources, diverse expertise, and years of development and testing ultimately converge in just a few hundred metric tons of hardware sent to the Moon. So a limited set of solutions, all drawn from an unproven set of alternatives, gets implemented in a remote environment under intense, critical public scrutiny. The uncertainties, programmatic risks, and visibility are unprecedented in terrestrial civil engineering and constitute a highly selective filter for candidate approaches to lunar base structures."16

These governing constraints need to be fully understood, and should be used as a first test of any MoonVillage concept.

Table 5. Physical environmental constraints for a MoonVillage.

\begin{tabular}{|c|c|}
\hline & Physical Environmental Issues \\
\hline Pressure differential & $\begin{array}{l}\text { Negligible outside atmosphere - hard vacuum for free } \\
\text { Habitable systems must withstand } 70-100 \mathrm{kPa}(10-15 \mathrm{psi}) \text { across entire enclosing surface, plus safety factors } \\
\text { Glass manufactured in vacuo can approach its theoretical strength }\end{array}$ \\
\hline $\begin{array}{l}\text { Diurnal cycle / temperature } \\
\text { extremes }\end{array}$ & $\begin{array}{l}\text { Synodic period } 29.53 \text { Earth days (at equator, almost } 15 \mathrm{hrs} \text { sunlight and } 15 \mathrm{hrs} \text { darkness) } \\
\text { Nearside, Full Earth } \sim 50 \times \text { brighter than Full Moon appears from Earth } \\
\text { Temperature range: }-171 \text { to } 111^{\circ} \mathrm{C} \text {. Temperature falls } \sim 5^{\circ} / \mathrm{hr} \text { at sunset. }\end{array}$ \\
\hline Radiation & $\begin{array}{l}\text { Continuous Galactic Cosmic Radiation and episodic high-energy solar protons, both isotropic from overhead } \\
\text { hemisphere }\end{array}$ \\
\hline Micrometeoroids & $\begin{array}{l}\text { Up to full encounter velocity of } \sim 20 \mathrm{~km} / \mathrm{s} \\
\text { Sensitive surfaces require shielding }\end{array}$ \\
\hline Lunar gravity & $\begin{array}{l}1.62 \mathrm{~m} / \mathrm{s}^{2} \text { at surface }(\sim 1 / 6 \mathrm{~g}) \\
\text { Gravity-stabilized operations. "Slender-span" structures possible. } \\
\text { Long-term physiological effects on living systems unknown. }\end{array}$ \\
\hline $\begin{array}{l}\text { Substrate mechanics / } \\
\text { dynamics }\end{array}$ & $\begin{array}{l}\text { Upper few } 100 \text { s } \mathrm{m} \text { are essentially rubble; few outcrops. 2-30-m thick regolith layer (5-10 m in mare regions) } \\
\text { Bulk density very low }\left(0.8-1.0 \mathrm{t} / \mathrm{m}^{3}\right) \text { in uppermost } \mathrm{mm} \text {, but reaches } 1.4-2.2 \mathrm{t} / \mathrm{m}^{3} \text { at } 3-\mathrm{m} \text { depth. Relative density } \\
\text { approaches } 100 \% \text { just a few meters down. } \\
30-50^{\circ} \text { angle of internal friction. More cohesive than most terrestrial soils }\left(0.1-1.0 \mathrm{kN} / \mathrm{m}^{2}\right) \text {. } \\
\text { Seismic disturbances can be neglected for structures }\end{array}$ \\
\hline $\begin{array}{l}\text { Dust composition / } \\
\text { behavior }\end{array}$ & $\begin{array}{l}50 \% \text { of regolith comprises particles finer than } 70 \mu \mathrm{m} \text { (unresolvable by naked eye) } \\
\text { Abrasive, electrostatically "sticky" in hard vacuum } \\
\text { Macroscopically, clumps together like damp beach sand }\end{array}$ \\
\hline $\begin{array}{l}\text { Available material } \\
\text { combinations }\end{array}$ & $\begin{array}{l}>98 \% \text { of surface material comprises } \mathrm{O}, \mathrm{Si}, \mathrm{Mg}, \mathrm{Fe}(9-14 \%), \mathrm{Ca}, \mathrm{Al}(9-18 \%), \mathrm{Ti}(9-18 \%) \text { in mare regions } \\
\text { Bulk deficient in } \mathrm{CHNPS} \text { (elements required for biomass) } \\
\text { Regolith enriched in } \mathrm{H} \text { from eons of solar wind } \\
\text { Glasses are found naturally, and can be made from available } \mathrm{CaO} \text { and } \mathrm{SiO}_{2}\end{array}$ \\
\hline
\end{tabular}

Table 6. Operations constraints for a MoonVillage.

\begin{tabular}{|l|l|}
\hline \multicolumn{1}{|c|}{ Operational Issues } \\
\hline Heat rejection & $\begin{array}{l}\text { Vacuum is a superb insulator. Regolith is a poor conductor. } \\
\text { Rejecting low-grade heat during lunar day is difficult } \\
\text { Cryogen storage requires temperatures down to } 20 \mathrm{~K} . \\
\text { Basalt melts at around 1500 K. }\end{array}$ \\
\hline Radiation safe-haven & Needed for all occupants, up to a few days at a time \\
\hline Human mobility envelope & $\begin{array}{l}\text { 2.5-m headroom might be necessary (20-45 degree body inclination, 1.25-4 m/s running speed). New } \\
\text { standards for riser/tread ratio and dimensions. }\end{array}$ \\
\hline $\begin{array}{l}\text { Habitat internal outgassing } \\
\text { and health environment }\end{array}$ & $\begin{array}{l}\text { Restricted materials list. } \\
\text { In situ vitreous and rock surfaces; radon risk unknown. }\end{array}$ \\
\hline $\begin{array}{l}\text { Accommodation of robotic } \\
\text { assembly, operations, and } \\
\text { maintenance }\end{array}$ & $\begin{array}{l}\text { Lunar architecture will predominantly be built, operated, and maintained by machines. Many kinds and degrees } \\
\text { of autonomy. }\end{array}$ \\
\hline Joining techniques & Tolerant, robust, and repeatable in situ joining techniques are an enabling major development \\
\hline Retrofitting & $\begin{array}{l}\text { High premium on reusing available equipment. } \\
\text { For economy, systems must be designed to be taken apart, reconfigured, re-outfitted, and re-verified. }\end{array}$ \\
\hline Expansion & For economy, architecture must be scarred for open-ended construction, including radiation shielding \\
\hline Disposal & $\begin{array}{l}\text { Recycling, stockpiling of engineering materials. } \\
\text { Long-term storage of nuclear waste. }\end{array}$ \\
\hline Staging environments & $\begin{array}{l}\text { Ground processing on Earth, Earth-to-orbit launch, LEO including debris, trans-GEO including van Allen belts, } \\
\text { high-thrust lunar landing }\end{array}$ \\
\hline
\end{tabular}




\section{MoonVillage Scale}

How a MoonVillage could work and be built, and the enabling capabilities for this to happen, are a strong function of its location, scale of operation, size and type of its population, and basis of technology including the life support of its population. Table 7 maps these parameters to the activity types detailed in Tables 1-4.

Thorough scientific exploration of the Moon - necessary for, among other goals, knowing what the Moon has to offer potential industrial-scale operations - requires global access, albeit at small scale. Since globally distributed sites can be reached most economically from space, this has two major implications. First, to be a useful architecture for such global exploration a MoonVillage would need to offer laboratory capabilities sophisticated enough to justify bringing samples to it from all over the Moon; and propellant production to enable re-use of the transportation systems doing it. Second, should exploration discover locations deserving of repeated traffic, satellite MoonVillages separated by vast geographical distances might arise. The Moon has as much surface area as Africa.

Appropriate practicum locations depend on both the results of scientific exploration and the intent of subsequent activities. Environmental management, kitchen science, habitation operations, and exploration-preparation activities can be done anywhere on the Moon; industrial operations cannot because they are resource dependent; and urban operations will only be needed and able to grow at industrial operations sites. This means that the first MoonVillage could be started almost anywhere as long as its local mobility capabilities supported diverse investigations, but only locations capable of supporting industrial-scale operations would allow MoonVillage growth.

Only once research crews give way to production-scale activities can the skill mix of occupants expand significantly. Specifically, industrial growth shifts the population balance from scientific researchers to robotics technicians and production managers. "Company town" demographics and governance would suffice until or unless the population got so large $\left(\sim 10^{3}\right)$ and diverse that it would constitute a genuine public.

Once urban growth begins, physical location is essentially fixed. Urbanism historically develops where positive feedback occurs between human density and operations efficiency. For a MoonVillage this means locations that

Table 7. Key MoonVillage parameters as a function of activity type.

\begin{tabular}{|c|c|c|c|c|}
\hline & Science & Practicum & Resources & Urbanism \\
\hline Location & $\begin{array}{l}\text { Globally distributed investigations: } \\
\text { Farside, poles, lava tubes, } \\
\text { highlands and maria. } \\
\text { Mare Imbrium and Oceanus } \\
\text { Procellarum, South Pole-Aitken } \\
\text { Basin. }\end{array}$ & $\begin{array}{l}\text { Localized to landing sites } \\
\text { (for general learning); and } \\
\text { to target sites (for unique } \\
\text { conditions) }\end{array}$ & $\begin{array}{l}\text { Highly localized based on } \\
\text { "ores", e.g., mare regolith, } \\
\text { KREEP soils, ice. } \\
\text { Within a site: based on } \\
\text { economics of recovery, } \\
\text { processing, and } \\
\text { transportation. }\end{array}$ & Essentially permanent \\
\hline $\begin{array}{l}\text { Scale of } \\
\text { operation }\end{array}$ & $\begin{array}{l}\text { Small } \\
\text { Governing factor: number of highly } \\
\text { trained disciplines. }\end{array}$ & $\begin{array}{l}\text { Small - Moderate } \\
\text { Governing factor: flexibility } \\
\text { and diversity of } \\
\text { experimental apparatus, } \\
\text { equipment, and materiel. }\end{array}$ & $\begin{array}{l}\text { Moderate - Large } \\
\text { Governing factors: market } \\
\text { demand; total mass of } \\
\text { specialized tools; power; } \\
\text { capacity of robotic agents. }\end{array}$ & $\begin{array}{l}\text { Large - Permanent } \\
\text { Governing factor: } \\
\text { profitability of exports. }\end{array}$ \\
\hline $\begin{array}{l}\text { Type of } \\
\text { crew }\end{array}$ & $\begin{array}{l}\text { Exploratory. } \\
\text { Field science and operations skills } \\
\text { (science:operations crew ratio on } \\
\text { the ISS is 1:5). }\end{array}$ & $\begin{array}{l}\text { Experimental, practical, } \\
\text { developmental. } \\
\text { Laboratory, applied science, } \\
\text { engineering, and operations } \\
\text { skills. }\end{array}$ & $\begin{array}{l}\text { Production, industrial. } \\
\text { Engineers and technicians for } \\
\text { mining, materials processing, } \\
\text { foundry, manufacturing, } \\
\text { assembly, construction, } \\
\text { operations, and maintenance. }\end{array}$ & $\begin{array}{l}\text { Public. } \\
\text { Governance, law } \\
\text { enforcement, administrative, } \\
\text { commercial, retail, } \\
\text { maintenance, medical, } \\
\text { social services... }\end{array}$ \\
\hline $\begin{array}{l}\text { Size and } \\
\text { focus of } \\
\text { population }\end{array}$ & $\begin{array}{l}10^{1}-10^{2} \text { onsite researchers guide } \\
\text { observations and experiments. } \\
\text { High leverage of the terrestrial } \\
\text { science community. }\end{array}$ & $\begin{array}{l}10^{1}-10^{2} \text { onsite researchers } \\
\text { guide adaptive experiments. }\end{array}$ & $\begin{array}{l}10^{2}-10^{3} \text { onsite work crew } \\
\text { manage robotic construction, } \\
\text { operations, production, and } \\
\text { maintenance }\end{array}$ & $\begin{array}{l}10^{3}-10^{6} \text { citizens exploit } \\
\text { specialized niches in a } \\
\text { robust urban ecology }\end{array}$ \\
\hline $\begin{array}{l}\text { Technology } \\
\text { type }\end{array}$ & $\begin{array}{l}\text { All equipment imported from Earth. } \\
\text { Field instruments, robots. } \\
\text { Mobile and centralized } \\
\text { laboratories. } \\
\text { Exploration access. }\end{array}$ & $\begin{array}{l}\text { Almost all equipment } \\
\text { imported from Earth. } \\
\text { Habitable workshops with } \\
\text { scientific equipment and } \\
\text { routine exterior exposure. } \\
\text { Heavy-duty robots. }\end{array}$ & $\begin{array}{l}\text { Industrial-duty, factory scale, } \\
\text { highly automated, well } \\
\text { supplied }\end{array}$ & $\begin{array}{l}\text { Architectural, meeting public } \\
\text { and domestic needs, safety } \\
\text { and security. } \\
\text { Mass produced, adaptable, } \\
\text { recyclable. } \\
\text { Extensible. }\end{array}$ \\
\hline Life support & ISS-derivative (physico-chemical) & $\begin{array}{l}\text { Heavily conditioned, robust } \\
\text { to variances }\end{array}$ & Industrially conditioned, tuned & $\begin{array}{l}\text { Biological and buffered, with } \\
\text { mechanical emergency } \\
\text { temporary backup }\end{array}$ \\
\hline
\end{tabular}


could be "crossroads" for lunar and Earth goods and services. Assuming a conservative pace of multi-national scientific exploration, potential locations for large-scale lunar urban development will be known within a few decades.

\section{Moon Village Startup and Growth}

The first steps to establish a MoonVillage depend on who might be willing to make the first investments. The "initial conditions" for all scenarios imaginable comprise just two classes of player and three classes of activity.

The players:

- Google Lunar X-Prize entrants, all of them Group-III Newspace players. To win the competition, they will generally focus on the simplest goal: mid-latitude, Nearside sites, perhaps with some proximity to historic sites.

- Exploratory governments. The most likely Group-I players (including the conduct of human exploration) would be China, Europe, and perhaps Russia. The most likely Group-II players would be India, Japan, and Korea.

The activities:

- Demonstration of capability. For the Google Lunar X-Prize the thresholds are specific, and the pressure of competition biases against other goals. For Group-I and Group-II players the thresholds are more malleable, mutually comparative, and related to prestige, collaborative partnerships, or both.

- Scientific knowledge. Goals for solar-system science are specified in the USA by the NRC "Decadal Survey" and include broad topics like the origin and evolution of telluric planets, the dynamical history of the solar system's first billion years, and the origin, transport, and interactions of volatile species on airless bodies in the inner solar system. ${ }^{17}$ Pragmatic goals for applied science include how to use lunar materials for constructive purpose.

- Operations experience. This ranges from small-scale lessons for specific robotic systems up through empirical principles needed to design sustained operations and systems for settling in on the Moon, as well as technology demonstrations for other destinations (e.g., Mars).

Any type of MoonVillage must build up from this foundation. Table 8 shows how growth could occur, through three phases tied directly to the activities in Tables 1-3 (Exploratory, Experimental, and Industrial Scaleup), based on the capabilities brought by the three classes of player. (The fourth and final phase, Urbanism, follows naturally and only from Phase III, and so is not tabulated here.) An order-of-magnitude scale of the total value of activities associated with each phase - a measure of the money flowing through the enterprise from all sources - immediately reveals the fundamental challenge for growing lunar development beyond the modest exploratory phase.

In the Exploratory Phase I, today's diverse players all participate to explore the Moon thoroughly. Most focus primarily on demonstrating prowess (to their constituents and peer group) at their respective capability levels. But by performing key measurements at diverse locations across the lunar globe, they together achieve a new and pivotal objective: learning what the Moon has to offer, and where.

The most likely location for Group-I players is one of the poles, due to contemporary evidence that usable volatiles are concentrated there. ${ }^{18,19}$ Because volatile enrichment, particularly in the form of water ice, comprises a potential early, practical resource for bootstrapping space activities, and because Group-I investments are enabling, a polar region is the most likely core location for a first MoonVillage. And because the polar surface environment has never been explored, it is an alluring location for non-US Group-I players seeking to establish their own distinctive mark as spacefarers and Moon explorers. Polar regions are known to be significantly different from the Luna and Apollo sites (lighting cycles, shadowing and temperatures, non-ubiquity of direct telecommunications with Earth, and perhaps even regolith trafficability).

For both scientific and feed-forward reasons, a Farside location would be important. First, a location shadowed from radio transmissions on and around Earth would enable revolutionary radio astronomy. Second, access to exposed mantle material in the enormous South Pole - Aitken Basin (one of the largest impact structures in the solar system) is key to reconstructing early solar-system history, and possibly for mining minerals not found elsewhere on the Moon. Third, Mars-operations rehearsals would be more realistic if systems and crew could not see Earth.

A Farside South Polar MoonVillage could support all these activities directly; however, a Nearside South Polar MoonVillage could also support them if it were equipped with significant expeditionary capabilities, including especially regional mobility. Thus a two-village architecture might arise: a primary Nearside MoonVillage, whose manufactured propellants are used for episodic transportation to and from a second, expeditionary Farside MoonVillage several hundred kilometers away. While the value of such a complex dual-village architecture cannot be assessed yet (radio-astronomy isolation requirements have not been determined, and the South Pole-Aitken Basin 
Table 8. Moon Village players mapped to developmental phases.

\begin{tabular}{|c|c|c|c|}
\hline & $\begin{array}{c}\text { Phase } 1 \\
\text { Exploratory }\end{array}$ & $\begin{array}{c}\text { Phase } 2 \\
\text { Experimental }\end{array}$ & $\begin{array}{c}\text { Phase } 3 \\
\text { Industrial Scaleup }\end{array}$ \\
\hline $\begin{array}{c}\text { Total } \\
\text { Activity }\end{array}$ & Up to $\sim \$ 10$ B & $\$ 10^{1}-10^{2} B$ & $\$ 10^{2}-10^{3} B$ \\
\hline $\begin{array}{l}\text { Group I } \\
\text { Players }\end{array}$ & $\begin{array}{l}\text { Demonstrate technologies that enable } \\
\text { human surface access, mobility, return, } \\
\text { night survival, polar ops, Farside ops. } \\
\text { Assure operations access throughout cis- } \\
\text { lunar space. } \\
\text { Obtain robotic delivery from Group II } \\
\text { (barter) and Group III (purchase). } \\
\text { Inventory and understand lunar } \\
\text { environments and resources. }\end{array}$ & $\begin{array}{l}\text { Build and commission shared core } \\
\text { infrastructure (power, network, roads, } \\
\text { routine operations, laboratories). } \\
\text { Develop techniques for routine } \\
\text { operations. } \\
\text { Demonstrate technologies and protocols } \\
\text { for advanced operations. } \\
\text { Establish and operate Farside radio } \\
\text { observatories. } \\
\text { Determine potential benefits and costs } \\
\text { of lunar utilization scenarios. }\end{array}$ & $\begin{array}{l}\text { Privatize core infrastructure. } \\
\text { Codify safety standards, zoning. } \\
\text { Develop international interplanetary } \\
\text { regulatory regime. } \\
\text { Provide security and defense. } \\
\text { Maintain operating environment that } \\
\text { allows commercial and public } \\
\text { activities. }\end{array}$ \\
\hline $\begin{array}{l}\text { Group II } \\
\text { Players }\end{array}$ & $\begin{array}{l}\text { Demonstrate robotic surface access, } \\
\text { delivery, mobility, and retrieval. } \\
\text { Enlarge and diversify the set of } \\
\text { locations explored. }\end{array}$ & $\begin{array}{l}\text { Globalize lunar activities. } \\
\text { Provide niche capabilities to core } \\
\text { infrastructure. } \\
\text { Provide operational redundancy and } \\
\text { diversity. } \\
\text { Conduct independent research. }\end{array}$ & $\begin{array}{l}\text { Graduate into Group I, and pull new } \\
\text { nations into Group II. } \\
\text { Diversify lunar population. } \\
\text { Diversify interplanetary economy. }\end{array}$ \\
\hline $\begin{array}{l}\text { Group III } \\
\text { Players }\end{array}$ & $\begin{array}{l}\text { Contract build systems specified by } \\
\text { Group I. } \\
\text { Demonstrate robotic surface access, } \\
\text { delivery, mobility, and retrieval. } \\
\text { Sell basic services to Groups I and II } \\
\text { (e.g., access, information, samples). }\end{array}$ & $\begin{array}{l}\text { Operate systems used by Group I. } \\
\text { Conduct independent research. } \\
\text { Sell routine operating services to } \\
\text { Groups I, II, and III (e.g., logistics, } \\
\text { maintenance). } \\
\text { Pilot marketable production: water, } \\
\text { propellant, mineral resources. }\end{array}$ & $\begin{array}{l}\text { Generate wealth by exporting lunar } \\
\text { products to Earth. } \\
\text { Sell lunar products and infrastructure } \\
\text { access and services to Groups I, II, } \\
\text { and III (e.g., water, oxygen, propellants; } \\
\text { power, networking, leases of space for } \\
\text { habitation and work, and equipment). } \\
\text { Expand lunar population. } \\
\text { Build up facilities and operations. }\end{array}$ \\
\hline
\end{tabular}

is not yet explored), it would provide ample opportunities for all three player groups interacting to conduct advanced activities.

Other locations will likely be determined by Phase I exploration to have marginal or even significant benefit for development. This determination is pivotal for revealing whether the scale of lunar industrial development will be forever limited by the pace of other spacefaring activities (i.e., because they would comprise a customer for lunarmanufactured propellants), or be unleashed by Earth's appetite for material resources (e.g., rare-Earth elements).

We know from Apollo samples and orbital remote sensing that two large regions on the Moon are relatively enriched in KREEP elements $\mathrm{Fl}, \mathrm{Na}, \mathrm{K}, \mathrm{P}, \mathrm{Cl}, \mathrm{Zr}$, Th, $\mathrm{U}$, and the rare-Earth elements scandium, yttrium, lanthanum, cerium, praseodymium, neodymium, samarium, europium, gadolinium, terbium, dysprosium, holmium, erbium, thulium, ytterbium, and lutetium) ${ }^{20}$ While not technically rare on Earth ("Earth" here is an old term for "oxide"), these latter elements enable engineered materials for high-tech applications including alloys, glasses, ceramics, magnets, infrared lasers, LEDs, and medical devices. Phosphorus is essential for biomass; the light alkalai metals are key electrolytes; and the light halogens make industrial acids when combined with hydrogen.

KREEP elements are incompatible with mineral crystal lattices, so they likely separated out as the lunar magma ocean solidified, concentrating in a layer between crust and mantle. However, from thorium measurements made by Lunar Prospector and analysis of returned samples, we know that KREEP is exposed on the surface in two broad regions: the South Pole-Aitken Basin on the Farside, and Oceanus Procellarum and Mare Imbrium on the Nearside. That these regions are antipodal indicates that they may be related: the stress pulse from the basin impact event $\sim 4.3 \mathrm{Ga}$ may have caused a massive intrusion of magma into the lower crust on the opposite side. ${ }^{21}$ KREEP terrains may be hold the best potential as a source of high-value mineral exports to Earth. Today's global rare-Earth element market totals about $\$ 5 \mathrm{~B},{ }^{22}$ only $1 / 20^{\text {th }}$ the rough investment cost for an Experimental (Phase 2) MoonVillage. It is conceivable that the terrestrial utilization market is elastic to abundant supply; however, the upside potential is unknown.

The criticality of export-based utilization of lunar mineral resources in controlling the pace of lunar development cannot be overstated. There are really only three scenarios: 
- Growth Scenario 1 - Fast. Extraction of rare elements with extremely high value on Earth is found to be practical. The introduction of external wealth into the mass-market terrestrial economy stimulates rapid, industrial-scale development of the Moon, within just decades. This scenario depends on positive feedback between resource practicality and increased industrial usage on Earth.

- Growth Scenario 2 - Slow. In this scenario, export of mineral resources to Earth is a marginal, not transformational, opportunity. Extraction of more prosaic resources (e.g., oxygen, metals, semiconductors) is demonstrated comparably cost-effective to launching them from Earth, for in-space markets. The introduction of external wealth into this limited market promotes its growth and stimulates development of in-space manufacturing to support it, over century timescales. Wild cards affecting the pace of this scenario include potential competition from asteroidal resources; and possible industrial-scale growth of space solar power for Earth $^{23}$, whose construction might draw upon lunar resources.

- Growth Scenario 3 - Imperceptible. Humanity survives the transition to a sustainable, post-petroleum industrial economy without the use of space resources, either minerals or electrical power. Eventual expansion of humanity into space occurs for non-economic reasons over millennial timescales.

Scenario 3 is patently unpredictable and cannot be planned. The other two scenarios both depend on creation of economic value to attract private capital, without which lunar activities will always be constrained by government investment in "exploration" alone. Contemporary levels of funding as a fraction of GDP, and contemporary system development schedules, show that government projects could do little more than establish a small, science-based MoonVillage, and operate it for some decades.

\section{Hypothetical Scenario for Establishing a MoonVillage}

A hypothetical "future history" serves to illustrate how an international MoonVillage might actually be established and built up.

Early expeditions by Group-I players establish fundamental feasibility of basic operations, some infrastructure that can be used repeatedly, and technology that can be repurposed. This builds a context that can host Group-II players, who in turn demonstrate their own specialties in the shared environment on the Moon, and add operational resilience and capability extensions to the whole. Group-III players are then able to build up diverse capabilities and spin off profitable enterprises by adapting the principles pioneered by Groups I and II to produce and sell products and services to all three player groups.

At first the source of financing is government sponsorship of Group-I and Group-II activities, so growth is capped by those governments' allocations of budget to space "exploration." To shift from Practicum to Resources accompanied by gearing up for industrial-scale operations, populations above tens of people, and the pathway to permanence - funding must arise from other sources: non-space government-agency and commercial markets. Only Group-III players can access these markets, and need venture capital and debt-financed equity to do so. The enabler for this growth step is exports: minerals, metals, propellants, possibly ${ }^{3} \mathrm{He}$, entertainment, and experiences.

\section{A. Step 1a - Attention Returns to the Moon}

Someone wins the Google Lunar X-Prize. Multiple Group-III Newspace players demonstrate the capability to deliver payloads to Nearside mid-latitude sites. Funded by selling transportation services to industrialists and Group-I and Group-II players who invest in the Exploratory phase, they and Group-III Oldspace players extend their reach to more challenging terrains and locations.

\section{Space architecture is not required explicitly for this first step.}

\section{B. Step 1b - The World Arrives}

At the same time, two teams of Group-I players re-establish large-scale and human lunar access, funding development of transportation, robotic, and habitat systems by Group-III companies. ESA aims for a Farside South Polar site to prospect for volatiles; CNSA aims for the Nearside Oceanus Procellarum to prospect for rare minerals. Activity is milestone-limited by the human space flight budgets of the Group-I players.

Space architecture is limited: Orion, Dragon, and CST-100 type transportation capsules; and possibly pressurized rovers and campsite-type expedition habitats, all Class 1 systems. ${ }^{5}$

Steps $1 \mathrm{a}$ and $1 \mathrm{~b}$ together achieve the first phase, Exploration. The Moon is globally surveyed mineralogically and physically. Activity is rate-limited by the exploration budgets of science agencies and first-adopter entrepreneurs. 


\section{Step 2a-MoonVillage Founded}

ESA and RSA together locate the first MoonVillage by beginning the buildup of surface assets via repeated visits to the same site. The key assets, mutually iterative but listed here in order of strict need, are: ${ }^{24}$

- Power generation and storage

- Rovers and construction robots

- Primitive siteworks: radiation shielding, dust fixing, roadbeds, and lander debris berms

- Habitation complex comprising pre-integrated modules (Class 1) brought from Earth and assembled onsite (Class 2) with regolith-based radiation shielding (Class 3$)^{6}$

- Laboratories for physiology, geology, practicum, and closed ecology. ${ }^{25}$

The scale of this project is significant, different from but on par with the International Space Station; the five asset classes listed here provide ample challenges and opportunities for any space enterprises who choose to participate as MoonVillage citizens.

Following the ISS model, Group-I governments negotiate partner deals with Group-II governments, and subdivide services into competitive opportunities for diverse Group-III Oldspace and Newspace companies, thereby shifting their own investment focus to utilization. Activity remains rate-limited by the space exploration budgets of the Group-I and Group-II governments.

Space architecture expands significantly: ${ }^{26}$

- $\quad$ Predictive and survey-based site planning

- Operations-reconciled design of expandable infrastructure systems

- Robotically mediated system construction

- Modular and expandable Class 2 habitats with integrated Class 3 in situ shielding and routine EVA

- Landing pads and roads that reconcile proximity with debris shielding, dust control, and trafficability

- Accommodations for the 1/6 g environment, conducive to a wide range of human occupancy, from privacy to group assembly for culturally diverse and transient crews

- Laboratories designed for specialized research, including large-volume experiments and routine exchange with the exterior.

Step 2 is the gateway from what has been done before to typical depictions of extensive lunar operations. Comparing the tough challenges implicit in the space-architecture needs to the history of ISS development and operations reveals instantly how hard this step will be to fund and to achieve. This comparison alone makes clear how founding a MoonVillage must be an international project - no current player has the capacity to do it alone.

\section{Step 2b - MoonVillage as University and Business Park}

The MoonVillage becomes a "magnet" research center promoting simultaneous progress in multiple fields:

- Detailed analysis of rock, mineral, and volatiles samples collected all over the Moon without the need always to return them to Earth

- Empirical development of practical operations and protocols for life support, dust control, radiation mitigation, and maintenance

- Construction and support of Farside radio telescopes

- Experimentation with techniques for construction including sintering, additive manufacturing, and cast basalt; resource extraction; production, use, and recycling of engineering materials. An example is large-scale selective microwave sintering. ${ }^{27}$

- Trial use of substances produced in situ from lunar resources: breathing air, drinking water, cryogenic propellants, refined metals, glasses, and semiconductors

- Demonstration of SSP (space solar power) beamed from an Earth-Moon Lagrange point to the lunar surface, which would allow continuous industrial-scale operation without nighttime power storage or nuclear reactors

- Experimentation with living systems in lunar conditions; ${ }^{28}$ plant cultivation, harvesting, and processing; microbial ecology; animal husbandry

- Initiation of modular ecological life support, following a complex capability progression: experimental at first, then as parallel hot backup, then as capacity buffer, and finally as vital infrastructure

- Robot and system maintenance and repair - a major business opportunity

- Medical care

- Entertainment for terrestrial markets. 
Collaborators from Groups I, II, and III conduct and commission experiments according to their respective interests, priorities, and sponsors. Competition for delivery and operations services diversifies, introducing more MoonVillage citizens. The number of players increases as barriers to entry fall: transportation to the MoonVillage can be purchased commercially; operation of experiments can be bartered or purchased; eventually, everything required for onsite human visits can be bought rather than developed. Activity growth begins to escape the constraint of government exploration budgets, because private interests that stand to gain by industrializing lunar resources start to "pull" the pace of research.

Space architecture becomes more sophisticated:

- Retrofitting of systems already in operation

- Habitats and laboratories optimized rather than general-purpose: specific occupant demographics, and specialized equipment and provisions

- Maintenance shops

- System designs based on emergent knowledge, e.g., biological adaptation, health maintenance, food production, and ecological life support in lunar conditions

- Development of Class 3 habitat systems, including structure elements, construction and assembly, integration of systems, verification, and outfitting.

Most of these capabilities are strictly essential to enable subsequent scaleup, because they drive costs significantly. Retrofitting and onsite maintenance allow reusability, as important for planetary architecture as it is for Earth-to-orbit transportation. Further, Class 3 habitats decouple the creation of habitable volume from the capacity and cost limitations of space transportation systems. And ecological life support keeps sustainment costs and infrastructure complexity from precluding populations between tens and hundreds.

Steps $2 \mathrm{a}$ and $2 \mathrm{~b}$ together accomplish the second phase, Experimentation. As a result, Group-III players in particular will know exactly how, and where, to invest to extract wealth from the Moon. Successful "prospecting," and an international regime that permits wealth extraction, constitute a pivot between the Antarctic model of sponsored fundamental research, and an economic development model that exploit lunar resources for growth. Failure to progress beyond the Antarctic model would arrest MoonVillage growth at this stage.

\section{E. Step 3 -MoonVillage Industrialized}

Production-scale industrial operations begin to dominate lunar activity. These buildups are sited where they are most cost-effective, which requires compromising among resource and power accessibility, transportation efficiency, and proximity to key support services.

SSP (space solar power) provided to the lunar Nearside from EM-L1, and to the lunar Farside from EM-L2, allows cost-efficient, large-scale, continuous production operations without nuclear power.

No matter the location of industrial sites, the MoonVillage continues to provide support services to the industrial community: propellant and other volatiles production, medical care, research facilities, and recreational facilities. It also continues to support basic research, by operating Farside radio observatories and by performing cutting-edge research in lunar science and applications.

The growth rate is limited only by the market for lunar products. The dominant players are Group III, which directly access investment resources from terrestrial capital markets and as they grow, constitute an additional sector in the terrestrial global economy by providing materials and services to in-space businesses; and materials to Earth.

In this penultimate step, space architecture diversifies: industrial-scale facilities of many types including factories, service centers, dormitories, and training centers; end-to-end food production and biologically mediated life support infrastructure; specialized recreation facilities including athletics, aquatics, assembly, concerts, clubs, parks, and other "shore leave" entertainments; and the beginning of civic facilities, as some inhabitants opt for permanent occupancy and begin raising families.

Finally, the MoonVillage becomes a tourist destination. The diversity of activities conducted, and the accommodations that will have been made for lunar worker recreation, comprise a unique destination for adventure travel. Competition for routine commercial transportation causes downward pressure on price and upward pressure on reliability. As industrial scale increases, lunar tourism becomes accessible to the high-end leisure travel market from Earth.

Step 3 achieves the third phase, Industrial Scaleup. The Moon becomes a profit center for the in-space and terrestrial economies. 


\section{F. Step 4 - Village to City}

The fourth and ultimate phase, lunar Urban Settlement, is not treated in detail here because the definitions and roles of lunar players beyond Step 3 cannot really be predicted. Nonetheless, they must somehow be like the roles and institutions inside contemporary terrestrial civilization. Citizens would live, workers would work, generations would grow, and governments would govern and provide for the public welfare. However, their "genetic" relationship to today's spacefaring players is neither direct nor relevant.

Space architecture graduates to treat the same range of needs and issues that characterize terrestrial architecture, as outlined in Table 4: complete accommodations for all stages, aspects, activities, and needs of human living.

\section{Conclusions}

The MoonVillage concept is technically viable from a space-architecture standpoint; Apollo surface operations and ISS implementation (assembled from elements provided by different nations and built by different contractors), taken together, prove this.

A MoonVillage could aim to be implemented using the space business park model, because the Moon offers clear opportunities to government space programs for exploration and science, as well as potential opportunities for profitable mining exports. Development via the mixed-use model is not assured, however. First, commercial viability of lunar resources for space-based and Earth-based economies cannot be known before a substantial Experimental phase occurs. And second, both Mir and the ISS provide counterexamples, with the lesson that repurposing government research laboratories for mixed use by diverse commercial tenants is not straightforward. To be more than a temporary project by multiple governments, a MoonVillage must accommodate mixed use that can attract private capital.

In almost all respects, a MoonVillage would represent a more advanced project than the ISS, which poses both challenges and opportunities. A major challenge is that potentially useful locations on the Moon are geographically dispersed and not interchangeable, implying the need for a meta-architecture comprising multiple nodes interconnected by transportation infrastructure enabled in turn by lunar resources. A major opportunity is that essential technical domains - including extraterrestrial excavation, processing, construction, and verification require engagement in experimentation, development and demonstration in situ by industries other than traditional aerospace. Reliable and scalable operations are a precondition for MoonVillage architecture more sophisticated than just a local aggregation of landers.

Incremental steps, with roles for all classes of lunar player, can be mapped to three enabling phases: Exploration, Experimentation, and Industrial Scaleup. Advancement to the third phase hinges on demonstrating the utility of lunar-based resources. The rate of advancement hinges on whether lunar resources are economically beneficial for only in-space uses (slow growth), or for terrestrial markets (fast growth). Use of lunar materials for industrial-scale implementation of space solar power for Earth is a potential crossover application between the in-space and forEarth markets. Long-term visions of lunar tourism and lunar urbanism are moot if the third phase is not realized.

In all cases, the pace of the first two phases is determined by the space exploration budgets committed by participating nations, because of the plethora of core capabilities that must be demonstrated before extra-government capital can be attracted. Of the foreseeable government players: CNSA has expressed interest but is simultaneously developing Earth-orbital station capability; ESA's resources are more modest and commitment to lead human lunar activity depends on concurrence by the member states; RSA has interest but thin resources; and the USA has dominating resources but little interest to date. ${ }^{29}$

However, among advanced space flight objectives, a MoonVillage uniquely offers key benefits that could be considered as motivation: proximity, incremental feasibility, routine visible operations, and economic potential. Out of a MoonVillage arises the opportunity to build multiple interplanetary businesses, thereby opening a genuinely new economic domain.

\section{Acknowledgments}

Sponsorship to present this work at the 2016 International Conference on Environmental Systems was provided by Caltech, Jet Propulsion Laboratory under contract to NASA, the National Aeronautics and Space Administration. 


\section{References}

${ }^{1}$ Wörner, J., ESA Director General Jan Wörner Meets the Press, International Astronautical Federation Global Networking Forum, $66^{\text {th }}$ International Astronautical Congress, 13 October 2015, Jerusalem.

${ }^{2}$ Foust, J., "FAA Advisory Group Endorses "Moon Village" Concept," Space News, URL: http://spacenews.com/faaadvisory-group-endorses-moon-village-concept/ [cited 7 February 2016].

${ }^{3}$ Laguipo, A., "ESA to Build 3D-Printed Moon Village for Astronauts by 2030," Tech Times, URL: http://www.techtimes.com/articles/121906/20160107/esa-to-build-3d-printed-moon-village-for-astronauts-by-2030.htm [cited 7 February 2016].

4"European Space Agency Eyes Future "Moon Village"," CNN website, URL: http://www.cnn.com/videos/ world/2016/01/12/exp-european-space-agency-eyes-future-moon-village.cnn [cited 7 February 2016].

${ }^{5}$ Kennedy. K., "Vernacular of Space Architecture," Out of This World: The New Field of Space Architecture, edited by A. S. Howe and B. Sherwood, AIAA, Reston, VA, 2009, Chapter 2, pp. 7-21.

${ }^{6}$ Cohen, M. M., and Benaroya, H., "Lunar-Base Structures," Out of This World: The New Field of Space Architecture, edited by A. S. Howe and B. Sherwood, AIAA, Reston, VA, 2009, Chapter 15, pp. 179-204.

${ }^{7}$ Nixon, D., International Space Station: Architecture Beyond Earth, Circa Press, London, 2016.

${ }^{8}$ Ledyard, J., Shishko, R., Tantardini, M., and Scimemi, S., exISS: privatizing LEO before the ISS end-of-life, study proposed to Keck Institute for Space Studies, 2016.

${ }^{9}$ Orphans of Apollo, Documentary film, directed by M. Potter, Free Radical Productions, 2008.

${ }^{10}$ Lauer, C., Hopkins, J., Kelso, H., Sherwood, B, and Andrews, D., "Mixed-Use Business Park Developments in Space: a Real Estate Paradigm," Engineering, Construction, and Operations in Space IV, edited by R. G. Galloway and S. Lokaj Proceedings of Space 94, ASCE, 1994, Vol. 2, pp. 1471-1481.

${ }^{11}$ Lauer, C., Hopkins, J., Andrews, D., and Kelso, H., "Legal and Regulatory Aspects of Low Earth Orbit Business Park Development," Space Manufacturing 10: Pathways to the High Frontier, edited by B. Faughnan, Proceedings of the $12^{\text {th }}$ SSIPrinceton Conference, 4-7 May 1995, pp. 325-336.

${ }^{12}$ Sherwood, B., Lauer, C., and Hopkins, J., "Government Actions to Enable Space Business Parks," Engineering, Construction, and Operations in Space V, edited by S. W. Johnson, Proceedings of Space 96, 1-6 June 1996, Albuquerque, NM, pp. 186-193.

${ }^{13}$ Smith, M. S., "Russia Downscales Lunar Program as Roscosmos Morphs into State Corporation," Space Policy Online, URL: http://www.spacepolicyonline.com/news/russia-downscales-lunar-program-as-roscosmos-morphs-into-state-corporation [cited 4 January 2016].

${ }^{14}$ Solovyov, D., "Russian Space Agency Scales Back Plans as Crisis Shrinks Budget," Reuters, URL: https://beta.finance.yahoo.com/news/russian-space-agency-scales-back-164735434.html [cited 7 February 2016].

${ }^{15}$ Jianping, Z., China Manned Space Program, International Astronautical Federation Global Networking Forum, 12 October $2015,66^{\text {th }}$ International Astronautical Congress, Jerusalem.

${ }^{16}$ Sherwood, B., "Introduction [to Chapter 14]: Design Constraints for Planet Surface Architecture," Out of This World: The New Field of Space Architecture, edited by A. S. Howe and B. Sherwood, AIAA, Reston, VA, 2009, p. 171.

${ }^{17}$ U.S. National Research Council, Vision and Voyages for Planetary Science in the Decade 2013-2022, Washington, DC: The National Academies Press, 2011.

${ }^{18}$ Pieters, C. M., Goswami, J. N., Clark, R. N., Annadura, M., Boardman, J., Buratti, B., Combe, J.-P., Dyar, M. D., Green, R., Head, J. W., Hibbitts, C., Hicks, M., Isaacson, P., Klima, R., Kramer, G., Kumar, S., Livo, E., Lundeen, S., Malaret, E., McCord, T., Mustard, J., Nettles, J., Petro, N., Runyon, C., Staid, M., Sunshine, J., Taylor, L. A., Tompkins, S., and Varanasi, P., "Character and Spatial Distribution of $\mathrm{OH} / \mathrm{H}_{2} \mathrm{O}$ on the Surface of the Moon Seen by M3 on Chandrayaan-1," Science, Vol. 326, Issue 5952, 23 October 2009, pp. 568-572.

${ }^{19}$ Colaprete, A., Elphic, R. C., Farrell, W. M., Hayne, P., Heldmann, J. L., Hibbitts, C. A., Hurley, D. M., Livengood, T. A., Lucey, P., Klaus, K., Kring, D. A., Patterson, W., and Sherwood, B., "Lunar Polar Volatiles: Assessment of Existing Observations for Exploration, Solar System Exploration Virtual Institute," white paper to NASA Human Exploration and Operations Mission Directorate, 12 January 2016.

${ }^{20}$ Lunarpedia, KREEP, URL: http://www.lunarpedia.org/index.php?title=KREEP [cited 7 February 2016].

${ }^{21}$ Kring, D. A., McGovern, P. J., Potter, R. W. K., Collins, G. S., Grange, M. L., and Nemchin, A. A., Lunar Magmatism Hypothesis, SSERVI Exploration Science Forum, 21 July 2015, Moffett Field, URL: https://ac.arc.nasa.gov/ p8bizoqvd76/?launcher $=$ false \&fcsContent $=$ true \&pbMode=normal.

${ }^{22}$ Mordor Intelligence, LLP, Global Rare Earth Elements (REE) Market Segmented by Element, Application and Geography Trends and Forecasts (2015-2020), January 2016, http://www.reportlinker.com/p03281947-summary/Global-Rare-EarthElements-REE-Market-Segmented-by-Element-Application-and-Geography-Trends-and-Forecasts.html [cited 24 April 2016]

${ }^{23}$ Sherwood, B., "Space Architecture for Industrial-Scale Space Solar Power, AIAA 2012-3574, 42 ${ }^{\text {nd }}$ International Conference on Environmental Systems, AIAA, 15-19 July 2012, San Diego, CA.

${ }^{24}$ Sherwood, B., "Site Constraints for a Lunar Base," Space 90: Engineering, Construction and Operations, edited by S. W. Johnson and J. P. Wetzel, ASCE, New York, 1990, pp. 984-993. 
${ }^{25}$ Sherwood, B., "Module Architecture for In Situ Space Laboratories," AIAA 2010-6048, Proceedings of $40^{\text {th }}$ International Conference on Environmental Systems, Barcelona, July 2010.

${ }^{26}$ Sherwood, B., "Lunar Base Elements Designed for Robotic Operations," Space 90: Engineering, Construction and Operations, edited by S. W. Johnson and J. P. Wetzel, ASCE, New York, 1990, pp. 994-1004.

${ }^{27}$ Khoshnevis, B., and Zhang, J., "Selective Separation Sintering - An Additive Manufacturing Approach for Fabrication of Ceramic and Metallic Parts with Application in Planetary Construction," AIAA 2015-4450, Space 2015 Conference \& Exposition, AIAA, 31 August-2 September 2015, Pasadena, CA.

${ }^{28}$ Rodgers, E. M., Simon, M.A., Antol, J., Chai, P. R., Jones, C. A., Klovstad, J. J., Neilan, J. H., Stillwagen, F. H., Williams, P. A., Bednara, M., Guendel, A., Hernandez, J., Lewis, W., Lim, J., Wilson, L., and Wusk, G., "Multigenerational Independent Colony for Extraterrestrial Habitation, Autonomy, and Behavior Health (MICEHAB): An Investigation of a Long-Duration, Partial Gravity, Autonomous Rodent Colony," AIAA 2015-4604, Space 2015 Conference \& Exposition, AIAA, 31 August-2 September 2015, Pasadena, CA.

${ }^{29}$ Patel, N., "When Will Astronauts Go Back to the Moon?" INVERSE, URL: https://www.inverse.com/article/10697-whenwill-astronauts-go-back-to-the-moon [cited 7 January 2016]. 